\title{
Mechanisms Permitting Nephrotic Patients to Achieve Nitrogen Equilibrium with a Protein-restricted Diet
}

\author{
Bradley J. Maroni, ${ }^{\star}$ Cathy Staffeld, ${ }^{\star}$ Vernon R. Young, ${ }^{\S}$ Amita Manatunga, ${ }^{\ddagger}$ and Karen Tom* \\ *Department of Medicine and George M. O’Brien Research Center for Diseases of the Kidney, and the ${ }^{\ddagger}$ Department of Biostatistics, \\ Rollins School of Public Health, Emory University, Atlanta, Georgia 30322; and ${ }^{\S}$ Laboratory of Human Nutrition, Massachusetts Institute \\ of Technology, Cambridge, Massachusetts 02142
}

\begin{abstract}
Clinical experience suggests nephrotic patients are at risk for malnutrition. To determine if nephrotic patients can adapt successfully to a protein-restricted diet, nephrotic (glomerular filtration rate, $52 \pm 15 \mathrm{ml} / \mathrm{min}$; urinary protein [Uprot.], 7.2 \pm 2.2 grams/d) and control subjects completed a crossover comparison of diets providing 0.8 or 1.6 grams protein (plus 1 gram protein/gram Uprot.) and $35 \mathrm{kcal}$ per kg per day. Nitrogen balance $\left(B_{N}\right)$ was determined and whole body protein turnover measured during fasting and feeding using intravenous L-[1- $\left.{ }^{13} \mathrm{C}\right]$ leucine and intragastric $\mathrm{L}-[5,5,5-$ ${ }^{2} \mathrm{H}_{3}$ ]leucine. $\mathrm{B}_{\mathrm{N}}$ was positive in both nephrotic and control subjects consuming either diet and rates of whole-body protein synthesis, protein degradation, and leucine oxidation did not differ between groups. In both nephrotic and control subjects anabolism was due to a suppression of whole-body protein degradation and stimulation of protein synthesis during feeding. The principal compensatory response to dietary protein restriction was a decrease in amino acid oxidation and this response was the same in both groups. With the low protein diet leucine oxidation rates during feeding correlated inversely with Uprot. losses $(r=-0.83 ; P<$ 0.05). Conclusions: (a) a diet providing 0.8 gram protein (plus 1 gram protein/gram Uprot.) and $35 \mathrm{kcal}$ per kg per day maintains $B_{N}$ in nephrotic patients; $(b)$ nephrotic patients activate normal anabolic responses to dietary protein restriction (suppression of amino acid oxidation) and feeding (stimulation of protein synthesis and inhibition of protein degradation); (c) the inverse correlation between leucine oxidation and Uprot. losses suggests that proteinuria is a stimulus to conserve dietary essential amino acids. ( $J$. Clin. Invest. 1997. 99:2479-2487.) Key words: nephrotic syndrome • leucine turnover • nitrogen balance • protein synthesis
\end{abstract}

This paper was presented, in part, at the annual American Society of Nephrology meeting in Orlando, FL, 26-29 October 1994 and has been published in abstract form (J. Am. Soc. Nephrol. 1994. 5:343a).

Address correspondence to Bradley J. Maroni, Renal Division, Emory University, WMRB Room 338, 1639 Pierce Drive, Atlanta, GA 30322. Phone: 404-727-2522; FAX: 404-727-3425.

Received for publication 6 September 1996 and accepted in revised form 11 February 1997.

J. Clin. Invest.

(C) The American Society for Clinical Investigation, Inc.

0021-9738/97/05/2479/09 \$2.00

Volume 99, Number 10, May 1997, 2479-2487

\section{Introduction}

Clinical experience suggests that patients with the nephrotic syndrome (i.e., $\geq 3$ grams proteinuria/d) are at risk for malnutrition, but the impact of urinary protein losses on protein metabolism is unknown. High protein diets have been recommended to compensate for urinary protein (Uprot.) $)^{1}$ losses and to promote positive nitrogen balance $\left(\mathrm{B}_{\mathrm{N}}\right)(1,2)$, but when Kaysen et al. measured albumin turnover and excretion in nephrotic subjects fed sequentially 1.6 or $0.8 \mathrm{grams} / \mathrm{kg} / \mathrm{d}$ of protein and $35 \mathrm{kcal} / \mathrm{kg} / \mathrm{d}$ for $10-14 \mathrm{~d}$, the lower protein diet (LPD) was associated with a significant reduction in albuminuria and a modest increase in serum albumin (3). Since proteinuria has been implicated as a risk factor for progressive renal insufficiency (4), a low protein diet could be used as adjunctive therapy to treat nephrotic patients.

We previously demonstrated in rats that proteinuria is perceived as a net reduction in dietary protein intake (intake minus urinary losses) and activates compensatory response(s) similar to those activated by a low protein diet; i.e., there was a reduction in amino acid oxidation and urea production, resulting in more efficient utilization of dietary amino acids and neutral or positive $\mathrm{B}_{\mathrm{N}}(5,6)$. Whether these responses occur in nephrotic patients is unknown, but if they do not, continuous protein losses could stimulate the degradation of body protein stores. Appropriate compensatory response(s) may not occur because Farr (1) and Blainey (2) concluded that the nephrotic syndrome is associated with protein depletion and that high protein diets were required to override this response. It is important to emphasize that in both studies, urinary protein losses increased when dietary protein intake was raised and serum albumin levels did not uniformly improve.

In short, proteinuria is a critical risk factor for progressive renal disease and a low protein diet can reduce proteinuria $(3,4)$. If protein-restricted diets can be given safely, the results of Kaysen et al. (3) would be clinically important. Not only can an LPD diet decrease Uprot. losses, but it may also reduce hypercholesterolemia (7) and slow the rate of progression of renal failure (8).

In nonnephrotic chronic renal failure (CRF) patients, most (9-11) but not all (12) studies suggest that diets providing either $\sim 0.6 \mathrm{~g}$ protein $/ \mathrm{kg} / \mathrm{d}$ or $\sim 0.3 \mathrm{~g}$ protein $/ \mathrm{kg} / \mathrm{d}$ supplemented with essential amino acids (EAA) or an amino acid-ketoacid (KA) mixture, yields neutral $B_{N}$. Whether these dietary regimens can produce neutral $B_{N}$ in patients with nephrotic syn-

1. Abbreviations used in this paper: $\mathrm{BCAA}$, branched-chain amino acids; $\mathrm{B}_{\mathrm{N}}$, nitrogen balance; BUN, blood urea nitrogen; $\mathrm{CRF}$, chronic renal failure; EAA, essential amino acids; HPD, high protein diet; KA, nitrogen-free ketoanalogs; $\alpha$-KIC, $\alpha$-ketoisocaproate; LPD, low protein diet; NUN, non-urea nitrogen; SBW, standard body weight; $\mathrm{U}$, urea nitrogen appearance; Uprot., urinary protein losses. 
drome is not known. A diet providing $0.8 \mathrm{~g}$ protein $/ \mathrm{kg} / \mathrm{d}$ is considered the "safe level of intake" for healthy adults (13) and the level recommended for patients with progressive renal disease (14). To determine the metabolic responses to dietary protein restriction in patients with the nephrotic syndrome, we studied control and nephrotic subjects while they consumed a diet providing 0.8 or $1.6 \mathrm{~g}$ protein $/ \mathrm{kg} / \mathrm{d}$ (plus $1 \mathrm{~g}$ protein $/ \mathrm{g}$ Uprot.). Dietary adequacy and the adaptive metabolic responses were assessed by measuring $\mathrm{B}_{\mathrm{N}}$ and whole-body protein turnover during each dietary period.

\section{Methods}

\section{Study protocol}

Five nephrotic patients (two females and three males: age $53 \pm 6 \mathrm{yr}$; range, 37 to $72 \mathrm{yr}$ old) and five healthy subjects (three females and two males: age $35 \pm 3 \mathrm{yr}$; range, 23 to $42 \mathrm{yr}$ old) completed the protocol. One additional nephrotic patient (patient No. 6; age 25) also completed the study but he had a spontaneous reduction in proteinuria from 9.9 grams/d before the study to 1.2 grams/d during the two Clinical Research Center (CRC) admissions. Since patient No. 6 was in partial remission (i.e., $\leq 3$ grams Uprot./d), his results were excluded from the $\mathrm{B}_{\mathrm{N}}$ and whole-body protein turnover analyses. However, patient No. 6 results were included when we examined the relationship between urinary protein losses and leucine oxidation rates (see Fig. 6).

Primary renal diagnoses included membranous glomerulonephritis (3), IgA nephropathy (1) and primary amyloidosis (1). No participant had diabetes mellitus, malnutrition or obesity (i.e., $<80 \%$ or $>120 \%$ of standard body weight [SBW], respectively) (15), or was taking medications known to affect protein metabolism. Antihypertensive and antihyperlipidemic medications were prescribed as required and metabolic acidosis was corrected (serum $\mathrm{HCO}_{3} \geq 24 \mathrm{mM}$ ) with supplemental sodium bicarbonate when necessary. Each patient also received a multivitamin (Nephrocap ${ }^{\mathrm{TM}}$; Fleming Co., Fenton, MO) and $\mathrm{CaCO}_{3}$ ( $\geq 1$ gram elemental calcium/d). This protocol was approved by the Human Investigations Committee at Emory University (Atlanta, GA) and a written, informed consent was obtained from each participant.

\section{CRC protocol}

Before the initial CRC admission, a history and physical exam was performed and a chemistry panel (SMA-18), complete blood count, urinalysis, and 24-h urine protein were obtained. Each subject then met with the research dietitian for anthropometric measurements and to design the metabolic diet taking into account individual food preferences. Protein and energy intake were calculated based on SBW
$(15,16)$ using the Nutritionist IV computer program (N-Squared Computing, San Bruno, CA). The diets provided either 0.8 or 1.6 gram protein, $35 \mathrm{kcal} / \mathrm{kg} \mathrm{SBW}$ per d, $\leq 12$ or $24 \mathrm{mg} / \mathrm{kg} \mathrm{SBW}$ per d phosphorus, and 2-4 grams sodium. The nephrotic patients received an additional gram of dietary protein for each gram of proteinuria (Uprot.). The quantity of dietary protein provided to replace urinary protein losses was constant during both dietary regimens. We provided $35 \mathrm{kcal} / \mathrm{kg}$ per $\mathrm{d}$ because this is the recommended energy intake for CRF patients (17).

The order of administration of each diet was random and to allow equilibration, prepackaged meals providing the prescribed intake were initiated $14 \mathrm{~d}$ before each CRC admission. Following a 4-d leadin period, a $5-\mathrm{d} \mathrm{B}_{\mathrm{N}}$ was performed during each 10-day CRC admission (Fig. 1). A complete blood count, SMA-18, and serum transferrin were measured on days 2 and 9, and the blood urea nitrogen (BUN) was obtained each morning. On day 2 , the $\left[{ }^{125} \mathrm{I}\right]$-Iothalamate clearance glomerular filtration rate (GFR) was performed as previously described (10) (one admission only for control subjects), and on day 3 the fractional recovery of ${ }^{13} \mathrm{CO}_{2}$ was measured during an infusion of $\mathrm{NaH}^{13} \mathrm{CO}_{3}$ (10). Since the background ${ }^{13} \mathrm{CO}_{2}$ enrichment of expired air may change during feeding, a "sham infusion" was performed on day 9 (10). Finally, as an index of the status of whole-body protein turnover, leucine kinetics were measured during fasting and feeding on day 10.

After the first CRC admission (period 1), participants consumed an ad libitum diet for a $\geq 4$-wk "wash-out" period. Participants began the alternative dietary regimen $14 \mathrm{~d}$ before the second CRC admission and then underwent an identical inpatient protocol.

\section{Materials}

L- $\left[1-{ }^{13} \mathrm{C}\right]$ leucine $\left(99 \mathrm{~mol} \%{ }^{13} \mathrm{C}\right), \mathrm{L}-\left[5,5,5-{ }^{2} \mathrm{H}_{3}\right]$ leucine (99 mol\% ${ }^{2} \mathrm{H}_{3}$ ), and sodium $-\left[{ }^{13} \mathrm{C}\right]$ bicarbonate $\left(99 \mathrm{~mol} \%{ }^{13} \mathrm{C}\right)$ were obtained from Tracer Technologies Inc. (Somerville, MA). Each labeled compound was determined to be sterile and pyrogen-free (Findley Research Inc., Fall River, MA). Plasma and infusate samples were stored at $-70^{\circ} \mathrm{C}$ until analyzed. Breath samples were collected using a latex balloon with a one way valve, (USAT, Rancho Cucamonga, CA), transferred to $15-\mathrm{ml}$ evacuated glass tubes (Venoject T-218U; Terumo Medical, Elkton, MD) and stored at room temperature until analyzed for ${ }^{13} \mathrm{CO}_{2}$ enrichment. Total $\mathrm{CO}_{2}$ production was determined by indirect calorimetry using a Deltatrac ${ }^{\mathrm{TM}}$ Metabolic monitor (Sensormedics, Anaheim, CA). $\left.{ }^{125} \mathrm{I}\right]$-Iothalamate (Glofil) was purchased from Isotex Diagnostics (Friendswood, TX) and plasma and urine radioactivity measured using a Beckman 5500B gamma counter (Beckman Instruments Inc., Fullerton, CA). Serum chemistries were performed by the Emory University Hospital Clinical Chemistry Laboratory using an Olympus AV 5000 autoanalyzer (Olympus Corp., Lake Success, NY). The 24-h urine protein excretion was the average of the consecutive 24-h urine collections performed during each 5-d $\mathrm{B}_{\mathrm{N}}$.

Metabolic Diet

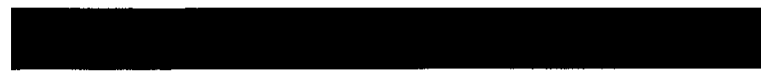

+4 day lead-in $\longrightarrow-5$ day Nitrogen balance $-t$

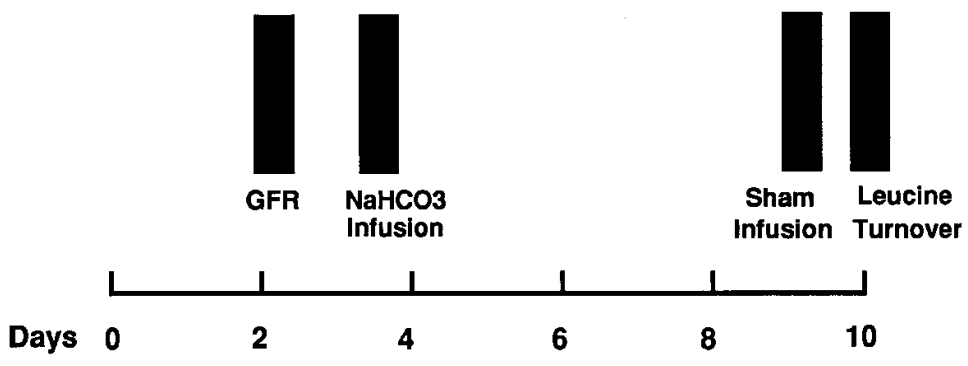

Figure 1. The 10-d CRC protocol. 


\section{Nitrogen balance}

During each balance period, daily 24-h urine collections were analyzed for total and urea nitrogen, and the pooled 5-d stool collection analyzed for total nitrogen. The nitrogen content of food, urine, and feces were determined using the micro-Kjeldahl method and urinary urea nitrogen was measured fluorometrically. $\mathrm{B}_{\mathrm{N}}$ was calculated as nitrogen intake $\left(\mathrm{I}_{\mathrm{N}}\right)$ minus urea nitrogen appearance $(\mathrm{U})$ minus nonurea nitrogen (NUN); $B_{N}=I_{N}-U-N U N$ (11). Nitrogen intake was determined by duplicate diet analysis and was corrected for uneaten food or emesis. Urea nitrogen appearance (U) was calculated as the algebraic sum of the mean urinary urea nitrogen (UUN) excretion rate, plus the daily change in the urea nitrogen pool (11). Nonurea nitrogen was calculated as total urinary nitrogen minus urinary urea nitrogen plus fecal nitrogen (18). Nitrogen balance determinations were corrected for unmeasured nitrogen losses estimated at 8 $\mathrm{mg} / \mathrm{kg}$ per d (13).

\section{Tracer infusion studies}

(a) Sham infusion. The contribution of the formula meal to background ${ }^{13} \mathrm{CO}_{2}$ enrichment was determined on day 9 by collecting expired breath samples during feeding using an identical protocol to that described for the whole-body leucine turnover, except that tracers were not infused $(10,19)$. To minimize its contribution to background ${ }^{13} \mathrm{CO}_{2}$ enrichment, foods with a low ${ }^{13} \mathrm{C}$ abundance were chosen for the formula meal (20). The steady-state ${ }^{13} \mathrm{CO}_{2}$ enrichment measured during the feeding phase of the sham infusion was then subtracted from the plateau ${ }^{13} \mathrm{CO}_{2}$ enrichment measured during the feeding phase of the $\mathrm{NaH}^{13} \mathrm{CO}_{3}$ and $\mathrm{L}-\left[1-{ }^{13} \mathrm{C}\right]$ leucine infusions $(10,19)$.

(b) Bicarbonate kinetics. We measured ${ }^{13} \mathrm{CO}_{2}$ recovery on day 3 of each CRC admission during an 8-h infusion of $\mathrm{NaH}^{13} \mathrm{CO}_{3}(5.4$ $\mu \mathrm{mol} \cdot \mathrm{kg}$ prime; $3.9 \mu \mathrm{mol} \cdot \mathrm{kg}^{-1}$ per $\mathrm{h}^{-1}$ constant infusion), using an identical protocol to that described for the whole-body leucine turnover. The fraction of infused $\mathrm{NaH}^{13} \mathrm{CO}_{3}$ recovered in expired air as ${ }^{13} \mathrm{CO}_{2}(F R)$ was calculated as described (21):

$F R=\mathrm{F}^{13} \mathrm{CO}_{2} / i \mathrm{NaH}^{13} \mathrm{CO}_{3}$

where $\mathrm{F}^{13} \mathrm{CO}_{2}$, is the rate of ${ }^{13} \mathrm{CO}_{2}$ production $\left(\mu \mathrm{mol} \cdot \mathrm{kg}^{-1}\right.$ per $\left.\mathrm{h}^{-1}\right)$, and $i \mathrm{NaH}^{13} \mathrm{CO}_{3}$ is the $\mathrm{NaH}^{13} \mathrm{CO}_{3}$ infusion rate $\left(\mu \mathrm{mol} \cdot \mathrm{kg}^{-1}\right.$ per h$\left.{ }^{-1}\right)$. Leucine oxidation rates were calculated using the individual recovery values from each participant.

(c) Leucine kinetics. On the morning of the tracer leucine infusion, one retrograde intravenous catheter was placed in a superficial hand vein for blood sampling, while a second catheter was placed antegrade in a contralateral forearm vein for isotope infusion. Arterialized blood samples were obtained by placing the arm with the retrograde catheter in a temperature controlled "hot box" $\left(58-60^{\circ} \mathrm{C}\right)(22)$. Baseline blood and breath samples were collected at 7:30 a.m. and 7:45 a.m. for determination of background ${ }^{13} \mathrm{C}$ enrichment of plasma $\alpha$-ketoisocaproate $(\alpha-\mathrm{KIC})$ and expired $\mathrm{CO}_{2}$. At 8:00 a.m., a priming dose of $\mathrm{NaH}^{13} \mathrm{CO}_{3}(0.11 \mathrm{mg} / \mathrm{kg})$ and $\mathrm{L}-\left[1-{ }^{13} \mathrm{C}\right]$ leucine $\left(2.0 \mu \mathrm{mol} \cdot \mathrm{kg}^{-1}\right)$ were given, followed by a constant infusion of $\mathrm{L}-\left[1-{ }^{13} \mathrm{C}\right]$ leucine $\left(4.2 \mu \mathrm{mol} \cdot \mathrm{kg}^{-1}\right.$ per $\left.\mathrm{h}^{-1}\right)$ over $8 \mathrm{~h}$. During the last $41 / 2 \mathrm{~h}$ of the infusion (11:30 a.m.-4 p.m.) an isocaloric, isonitrogenous liquid meal (supplemented with $\mathrm{L}-\left[5,5,5-{ }^{2} \mathrm{H}_{3}\right]$ leucine) representing $1 / 3$ of the day's intake of protein and calories was given in equal portions at 30-min intervals to study the response to feeding. Blood and expired breath were sampled at 15-min intervals between 10:30-11:30 a.m. and 3:00-4:00 p.m. while at isotopic steady-state. At 9:30 a.m. and 2:00 p.m., $\mathrm{CO}_{2}$ production was measured over $30 \mathrm{~min}$ by indirect calorimetry.

(d) Calculations. Whole-body leucine turnover was calculated using standard formulae (23) and plasma $\alpha$-KIC enrichment, since the latter more closely approximates the average whole-body intracellular enrichment for leucine (24). Leucine flux (Q) $\left(\mu \mathrm{mol} \cdot \mathrm{kg}^{-1} \mathrm{per} \mathrm{h}^{-1}\right)$ is calculated as:

$\mathrm{Q}=\mathrm{i}\left[E_{\mathrm{i}} / E_{\mathrm{KIC}}-1\right]$ where $\mathrm{i}$, is the $\mathrm{L}-\left[1-{ }^{13} \mathrm{C}\right]$ leucine infusion rate $\left(\mu \mathrm{mol} \cdot \mathrm{kg}^{-1}\right.$ per h$\left.{ }^{-1}\right) ; E_{\mathrm{i}}$, is the infusate $\mathrm{L}-\left[1-{ }^{13} \mathrm{C}\right]$ leucine enrichment (atoms percent excess); and $E_{\mathrm{KIC}}$, is the plasma $\mathrm{L}-\left[1-{ }^{13} \mathrm{C}\right] \alpha-\mathrm{KIC}$ enrichment at isotopic plateau (atoms percent excess).

The rate of ${ }^{13} \mathrm{CO}_{2}$ released $\left(\mu \mathrm{mol} \cdot \mathrm{kg}^{-1}\right.$ per $\left.\mathrm{h}^{-1}\right)$ from $\mathrm{L}-\left[1-{ }^{13} \mathrm{C}\right]$ leucine catabolism is:

$\mathrm{F}^{13} \mathrm{CO}_{2}=F_{\mathrm{CO}_{2}} \times E \mathrm{CO}_{2} / \mathrm{W}[60 \times 44.6 / 100 \times F R]$

where $\mathrm{FCO}_{2}$ is the $\mathrm{CO}_{2}$ production rate $\left(\mathrm{cm}^{3} \cdot \mathrm{min}^{-1}\right) ; \mathrm{ECO}_{2}$, the ${ }^{13} \mathrm{CO}_{2}$ enrichment in expired air at isotopic steady state (atoms percent excess); and $\mathrm{W}$, the subject's weight $(\mathrm{kg})$. The constants $60 \mathrm{~min} \cdot \mathrm{h}^{-1}$ and $44.6 \mu \mathrm{mol} \cdot \mathrm{cm}^{3}$ (at STP) convert $F \mathrm{CO}_{2}$ to $\mu \mathrm{mol} \cdot \mathrm{h}^{-1}$; the factor $100 \mathrm{con}$ verts atoms percent excess to a fraction; and $F R$ is the fraction of ${ }^{13} \mathrm{CO}_{2}$ released from the oxidation of $\mathrm{L}-\left[1-{ }^{13} \mathrm{C}\right]$ leucine which is recovered in expired air.

The rate of leucine oxidation (C) $\left(\mu \mathrm{mol} \cdot \mathrm{kg}^{-1}\right.$ per $\left.\mathrm{h}^{-1}\right)$ is calculated as:

$\mathrm{C}=\mathrm{F}^{13} \mathrm{CO}_{2}\left[1 / E_{\mathrm{KIC}}-1 / E_{\mathrm{i}}\right] \times 100$

from which the rate of leucine incorporation into protein can be calculated as:

$\mathrm{S}=\mathrm{Q}-\mathrm{C}$

The rate of leucine appearance from protein (B) is the difference between leucine flux $(\mathrm{Q})$ and dietary leucine intake $(\mathrm{I})$ :

$\mathrm{B}=\mathrm{Q}-\mathrm{I}$

When subjects are studied in the postabsorptive state, $\mathrm{I}=0$, and the rate of leucine appearance $(\mathrm{Q})$ into the plasma compartment $\left(\mu \mathrm{mol} \cdot \mathrm{kg}^{-1}\right.$ per $\left.\mathrm{h}^{-1}\right)$ is equal to endogenous leucine appearance (B), and hence is an index of net proteolysis.

In the fed state, dietary amino acids must pass through the splanchnic bed where some amino acids may be removed. Failure to account for splanchnic removal of dietary leucine would underestimate the rate of protein breakdown (B) during feeding and the balance between $\mathrm{S}$ and $\mathrm{B}(25)$. Therefore, $\mathrm{L}-\left[5,5,5{ }^{2} \mathrm{H}_{3}\right]$ leucine was added to the liquid formula and the contribution of dietary leucine to total leucine flux calculated as previously described $(10,26)$. Since the $\left[{ }^{2} \mathrm{H}_{3}\right]$ leucine enrichment of the formula was known and the plasma $\left[{ }^{2} \mathrm{H}_{3}\right]$ leucine enrichment was measured, the fraction of circulating leucine derived from the meal was calculated $(10,19)$ :

$\mathrm{F}_{\mathrm{m}}=E_{\mathrm{p}}\left[{ }^{2} \mathrm{H}_{3}\right] / D\left[{ }^{2} \mathrm{H}_{3}\right]$

where $\mathrm{F}_{\mathrm{m}}$ is the fraction of plasma leucine from the meal; $E_{\mathrm{p}}\left[{ }^{2} \mathrm{H}_{3}\right]$, is the plasma $\left[{ }^{2} \mathrm{H}_{3}\right]$ leucine enrichment; and $D\left[{ }^{2} \mathrm{H}_{3}\right]$, is the dietary $\left[{ }^{2} \mathrm{H}_{3}\right]$ leucine enrichment.

Knowing the fraction of the circulating leucine derived from the meal $\left(\mathrm{F}_{\mathrm{m}}\right)$ and total leucine flux $(\mathrm{Q})$, the rate of dietary leucine entry (I) can be calculated:

$\mathrm{I}=\mathrm{F}_{\mathrm{m}} \times \mathrm{Q}$.

Finally, if the rate of total leucine flux $(\mathrm{Q})$ and dietary leucine entry (I) is known, leucine derived from endogenous protein breakdown (B) can be calculated; i.e., $\mathrm{B}=\mathrm{Q}-\mathrm{I}$.

\section{Analytical methods}

(a) Infusate and plasma amino acid concentrations. Infusate and plasma amino acid concentrations were measured using an amino acid analyzer (334; Beckman Instruments).

(b) Mass spectrometry analysis. All GC/MS analyses were performed using a Hewlett Packard 5890 Series II gas chromatograph coupled to a HP5988A quadrapole mass spectrometer (HewlettPackard Corp., Cupertino, CA). For the measurement of the ${ }^{2} \mathrm{H}_{3}$ leucine enrichments, plasma was extracted using the method of Adams (27) and the $\tau$-butyldimethylsilyl derivative prepared according to 
Chaves das Naves and Vasconcelos (28). Isotopic enrichments were determined by selected ion monitoring [M-57] ${ }^{+}$at $\mathrm{m} / \mathrm{z} 302$ and 305 corresponding to natural leucine and $\left[{ }^{2} \mathrm{H}_{3}\right]$ leucine, respectively. Measurement of the isotope enrichment of plasma $\alpha$-KIC was performed using the extraction and quinoxalinol derivatization procedures of Rocchicchioli et al. (29). The quinoxalinol-t-butyldimethysilyl derivative was then prepared according to the method of Langebeck et al. (30) and analyzed by selected ion monitoring [M-57 $]^{+}$at $\mathrm{m} / z, 259$ and 260 , corresponding to $\alpha$-KIC and $\left[{ }^{13} \mathrm{C}\right] \alpha$-KIC, respectively. All isotopic enrichments were measured against calibration standards and are expressed as the mole fraction above baseline.

(c) ${ }^{13} \mathrm{CO}_{2}$ content in expired air. The ${ }^{13} \mathrm{CO}_{2}$ enrichment of expired air was measured by isotope-ratio mass spectrometry (MAT Delta E; Finnigan, Bremen, Germany) as previously described (23).

Statistics. Values are reported as mean \pm SE. A threeway ANOVA was used to evaluate the impact of diet (HPD vs LPD), nutrient intake (i.e., fasting vs feeding), and disease on whole-body leucine turnover and plasma amino acids concentrations. A twoway ANOVA was used to compare $B_{N}$ measurements within and between nephrotic and control subjects consuming the high and low protein diets. Posthoc analyses were adjusted for multiple comparisons using the Bonferroni procedure. To determine whether the response was dependent upon the order of diet administration, all outcomes were initially tested for a sequence effect by including an additional variable representing sequence in the ANOVA. Treatment effects were considered significant at $P \leq 0.05$; sequence effects were considered significant at $P \leq 0.10$.

A sequence effect was suggested for total nitrogen output (diet $X$ sequence; $P=0.06$ ) and whole body leucine disappearance (i.e., protein synthesis) during feeding (diet $\times$ group $\times$ sequence; control subjects, $P=0.08$ ). To assess this we analyzed the data in two ways. First, we evaluated the initial period only and then we ignored the sequence effect by combining all the data. The conclusions were the same using either method so we have presented the results ignoring sequence.

\section{Results}

Clinical characteristics. The body weights and caloric intake of nephrotic and control subjects did not differ while consuming the high or low protein diets (Table I). Protein intake estimated from nitrogen analysis of a duplicate diet slightly exceeded the intake prescribed using the Nutritionist IV database and the protein intake of the nephrotic patients was $\sim 10 \%$
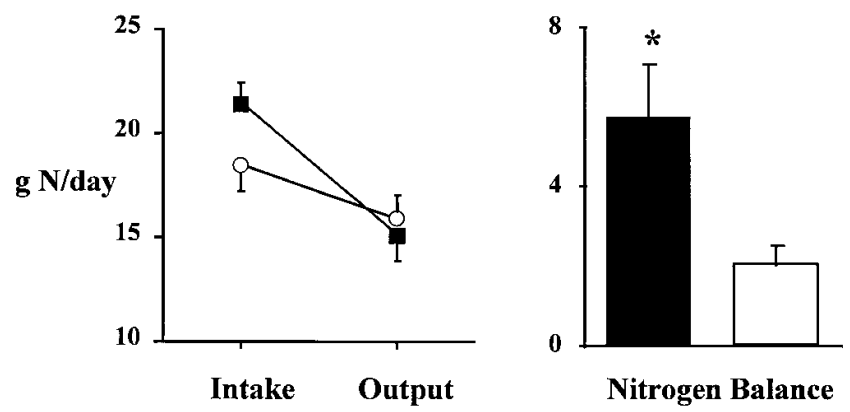

Figure 2. Nitrogen intake, nitrogen output, and nitrogen balance in nephrotic (solid symbols) and control subjects (open symbols) measured $\sim 3 \mathrm{wk}$ after initiating a diet providing 1.6 grams protein $/ \mathrm{kg}$ SBW per d (plus 1 gram protein/gram Uprot.). Values are mean \pm SE for five subjects in each group $\left({ }^{*} P<0.05\right.$ nephrotic vs control).

greater than the control subjects $(P=\mathrm{NS})$ with both dietary regimens. In both groups the BUN was significantly higher while consuming the HPD. In nephrotic patients, the serum cholesterol concentration was significantly higher and the serum albumin and transferrin concentrations significantly lower during both diets. In control subjects (but not nephrotic patients), the serum transferrin concentration increased significantly during the high protein diet. While consuming the low protein diet, urinary protein losses decreased in four of the five nephrotic patients by an average of $20 \%$, but this change was not significant $(P=0.08)$. The average GFR of nephrotic patients was $\sim 50 \%$ lower than that of the control subjects and patients with normal as well as advanced renal insufficiency participated in the study (range; GFR, 19-120 $\mathrm{ml} / \mathrm{min}$ ).

Nitrogen balance. Illustrated in Fig. 2 are the nitrogen intake, nitrogen output, and nitrogen balance $\left(B_{N}\right)$ measurements in nephrotic and control subjects while they consumed the high protein diet. Nitrogen intake (21.42 \pm 1.02 vs $18.46 \pm 1.26$ grams N/d; nephrotic vs control, respectively), total nitrogen output, and its components urea nitrogen appearance (11.15 \pm 1.07 vs $12.40 \pm 1.28$ grams $\mathrm{N} / \mathrm{d})$ and nonurea nitrogen $(3.94 \pm$

Table I. Clinical Characteristics of Nephrotic Patients and Control Subjects Measured while Consuming a Diet Providing 0.8 or 1.6 Grams Protein/kg per d (Plus 1 Gram Protein per Gram Proteinuria)

\begin{tabular}{|c|c|c|c|c|}
\hline & \multicolumn{2}{|c|}{ Nephrotic } & \multicolumn{2}{|c|}{ Control } \\
\hline & 0.8 & 1.6 & 0.8 & 1.6 \\
\hline & \multicolumn{4}{|c|}{ gram protein $/ \mathrm{kg} S B W$ per $d$} \\
\hline Weight $(\mathrm{kg})$ & $76.0 \pm 2.0$ & $75.9 \pm 2.1$ & $63.5 \pm 7.3$ & $63.4 \pm 7.3$ \\
\hline Caloric intake (kcal/kg SBW per d) & $34.1 \pm 0.6$ & $34.9 \pm 0.1$ & $35.0 \pm 0.0$ & $35.0 \pm 0.0$ \\
\hline Protein intake (gram/kg SBW per d) & $1.00 \pm 0.03$ & $1.85 \pm 0.04^{\ddagger}$ & $0.89 \pm 0.02$ & $1.68 \pm 0.04^{\ddagger}$ \\
\hline $\mathrm{BUN}(\mathrm{mg} / \mathrm{dl})$ & $23 \pm 7$ & $35 \pm 8^{\ddagger}$ & $9 \pm 1$ & $17 \pm 2^{\ddagger}$ \\
\hline Cholesterol (mg/dl) & $275 \pm 38^{*}$ & $285 \pm 44 *$ & $164 \pm 18$ & $166 \pm 18$ \\
\hline Serum albumin $(\mathrm{mg} / \mathrm{dl})$ & $2.3 \pm 0.4^{*}$ & $2.2 \pm 0.4 *$ & $3.5 \pm 0.1$ & $3.6 \pm 0.1$ \\
\hline Serum transferrin $(\mathrm{mg} / \mathrm{dl})$ & $186 \pm 21^{*}$ & $200 \pm 27 *$ & $269 \pm 10$ & $301 \pm 6^{\ddagger}$ \\
\hline Serum $\mathrm{HCO}_{3}(\mathrm{mg} / \mathrm{dl})$ & $27 \pm 1$ & $27 \pm 1$ & $28 \pm 0$ & $27 \pm 1$ \\
\hline Urine protein (gram/d) & $6.8 \pm 1.9 *$ & $8.2 \pm 2.4^{*}$ & $\leq 0.1$ & $\leq 0.1$ \\
\hline $\operatorname{GFR}(\mathrm{ml} / \mathrm{min})$ & $49 \pm 12 *$ & $54 \pm 18 *$ & & \\
\hline
\end{tabular}

Values are the mean \pm SE for five subjects $\left(* P<0.05\right.$, control vs nephrotic; ${ }^{\ddagger} P<0.05,0.8$ vs 1.6 grams protein $/ \mathrm{kg}$ per d diets). 
0.48 vs $3.51 \pm 0.41$ grams $\mathrm{N} / \mathrm{d}$ ) did not differ significantly between groups. Even when corrected for unmeasured nitrogen losses (13), both nephrotic and control subjects were in positive $\mathrm{B}_{\mathrm{N}}$ while consuming the high protein diet $(+5.73 \pm 1.34 \mathrm{vs}$ $+2.05 \pm 0.46$ grams N/d; $P<0.05$, nephrotic vs. control, respectively).

In Fig. 3 the same parameters are illustrated while participants consumed the protein-restricted diet. Nitrogen intake $(11.61 \pm 0.59$ vs $9.74 \pm 0.63$ grams $\mathrm{N} / \mathrm{d}$; nephrotic vs. control, respectively), total nitrogen output, and its components urea nitrogen appearance $(5.97 \pm 0.85$ vs $5.66 \pm 0.87$ grams $\mathrm{N} / \mathrm{d})$ and nonurea nitrogen $(3.68 \pm 0.36$ vs $2.48 \pm 0.18$ grams $N / d)$ did not differ between groups. In both groups, total nitrogen output, and its components urea nitrogen appearance and nonurea nitrogen were significantly lower with the LPD than HPD. Again, after correction for unmeasured nitrogen losses (13), both nephrotic and control subjects were in neutral or positive $B_{N}$ while consuming the protein restricted diet $(+1.35 \pm 0.69$; range, -0.33 to +3.45 grams $\mathrm{N} / \mathrm{d}$ vs $+1.09 \pm 0.40$; range, -0.34 to +1.95 grams $\mathrm{N} / \mathrm{d} ; P=\mathrm{NS}$, nephrotic vs. control, respectively). There was no correlation between GFR and $B_{N}$ in the nephrotic patients. Thus, despite the stress of continuous urinary protein loss (range: $3.0-14.5$ grams d), nephrotic patients achieved neutral or positive $B_{N}$ when dietary protein was restricted.

Leucine kinetics. In Figs. 4 and 5 are illustrated the rates of endogenous leucine appearance (protein degradation), nonoxidative leucine disposal (protein synthesis) and leucine oxidation measured in nephrotic patients and control subjects $\sim 3$ wk after initiating the high and low protein diets, respectively. Rates of whole-body protein degradation, protein synthesis, and leucine oxidation did not differ between nephrotic and control subjects during either dietary regimen. With the HPD, anabolism in both groups was due to a postprandial suppression of whole-body protein degradation ( -38 vs $-46 \%$; nephrotic vs control, respectively) and stimulation of protein synthesis ( +22 vs $+17 \%$; nephrotic vs control, respectively) (Fig. 4). Similar, albeit less pronounced changes were seen in response to feeding the LPD (protein degradation, -17 vs $-15 \%$; protein synthesis, +19 vs $+17 \%$; nephrotic vs. control, respectively) (Fig. 5) although the postprandial reduction of whole body protein degradation in control subjects was not statistically significant $(P<0.08)$. In response to feeding, iso-

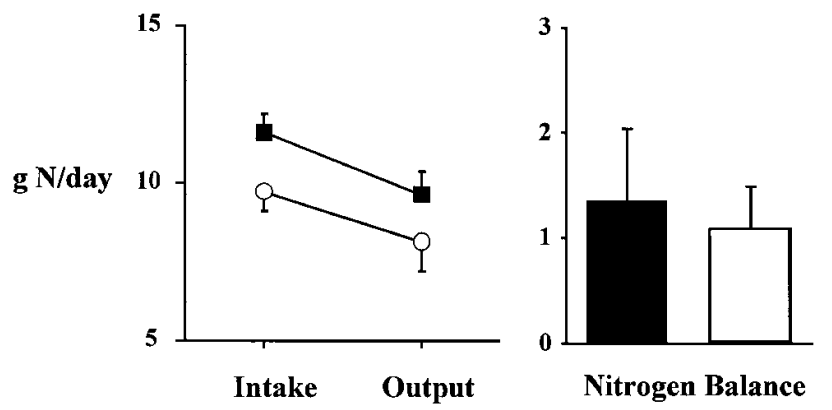

Figure 3. Nitrogen intake, nitrogen output, and nitrogen balance in nephrotic (solid symbols) and control subjects (open symbols) measured $\sim 3 \mathrm{wk}$ after initiating a diet providing 0.8 grams protein $/ \mathrm{kg}$ SBW per d (plus 1 gram protein/gram Uprot.). Values are mean \pm SE for five subjects in each group.
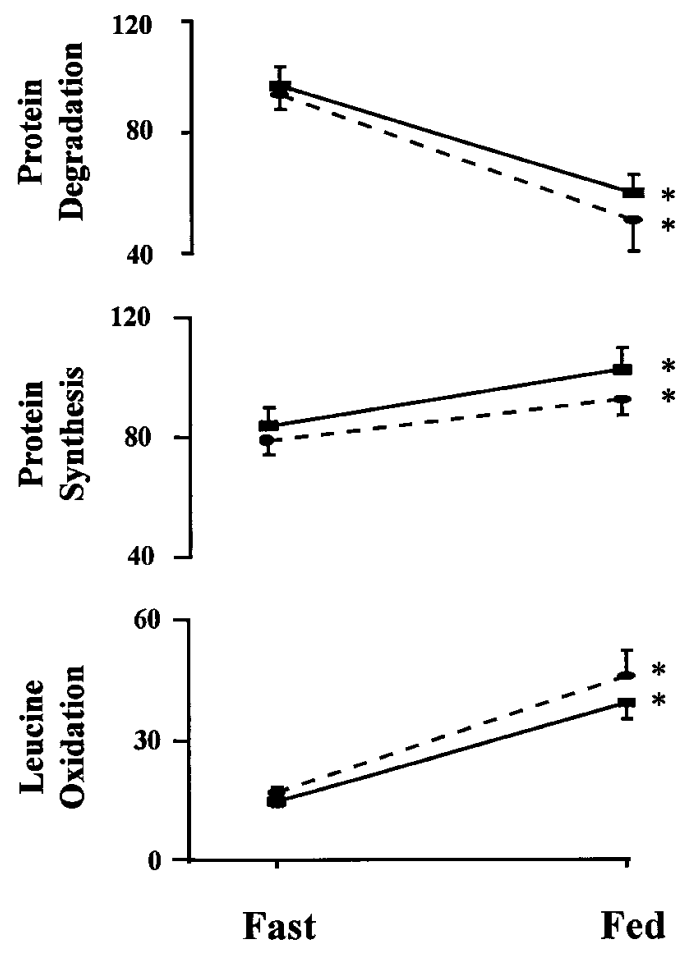

Figure 4. Rates of whole body protein degradation, protein synthesis, and leucine oxidation measured during fasting and feeding in nephrotic (solid squares with solid line) and control subjects (solid circles with dashed line) consuming a diet providing 1.6 grams protein $/ \mathrm{kg}$ SBW per d (plus 1 gram protein/gram Uprot.). Values are mean \pm SE for five subjects in each group.

topic leucine balance (i.e., protein synthesis minus degradation) became positive in both nephrotic and control subjects, and was significantly more positive with the high than the low protein diet (HPD, $+51.7 \pm 7.6$ vs $+40.4 \pm 7.0 ; \mathrm{LPD},+24.9 \pm 4.3$ vs $+11.8 \pm 4.3 ; \mu \mathrm{mol} / \mathrm{kg}$ per $\mathrm{h}$; nephrotic vs control, respectively).

In response to feeding leucine oxidation increased significantly in both groups (Figs. 4 and 5). Most importantly, in nephrotic as well as control subjects, leucine oxidation rates with feeding were significantly lower with the LPD compared with the HPD (i.e., nephrotic, $23.4 \pm 2.6$ vs $39.2 \pm 3.9$; control $27.4 \pm 1.5$ vs $45.9 \pm 6.3 \mu \mathrm{mol} / \mathrm{kg}$ per h; LPD vs HPD, respectively) indicating that nephrotic patients invoked normal compensatory responses designed to conserve dietary amino acids when protein (and hence leucine) intake was restricted.

Relationship between urinary protein losses and leucine oxidation. There was an inverse correlation between urinary protein losses and feeding leucine oxidation rates when nephrotic patients consumed the LPD $(r=-0.83 ; P=0.04)$, suggesting that proteinuria is a stimulus to conserve dietary amino acids when dietary protein is restricted (Fig. 6). A similar relationship $(r=-0.64)$ was also seen during fasting but the range of oxidation rates was smaller and the correlation was not significant $(P=0.17)$.

There was no significant correlation between leucine oxidation and proteinuria when nephrotic patients consumed a high protein (and hence, high leucine) diet. This is not surpris- 

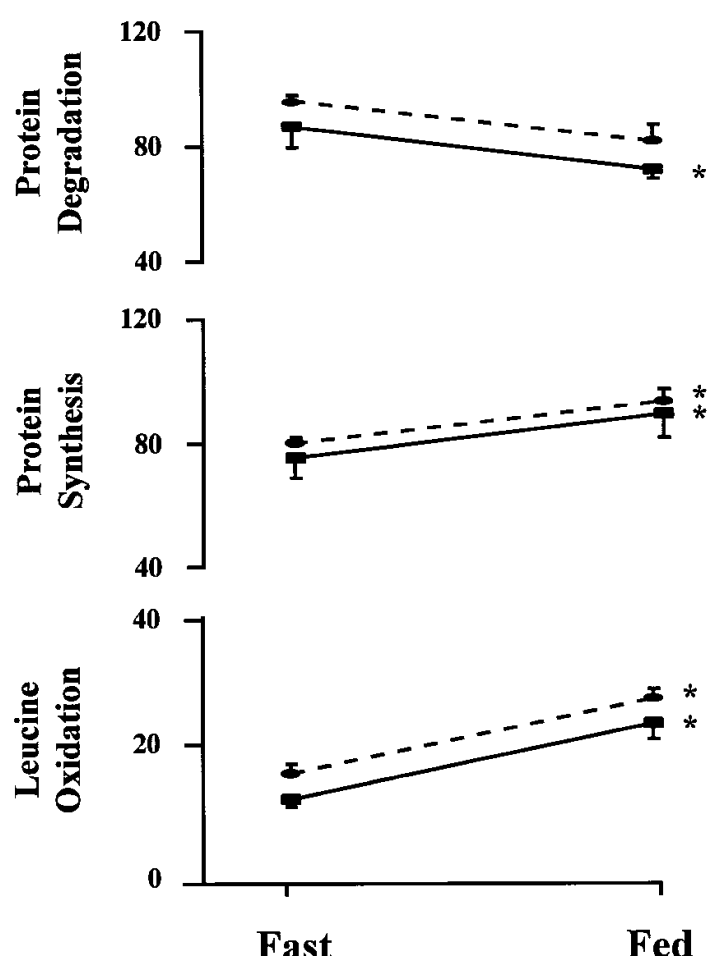

Figure 5. Rates of whole body protein degradation, protein synthesis, and leucine oxidation measured during fasting and feeding in nephrotic (solid squares with solid line) and control subjects (solid circles with dashed line) consuming a diet providing 0.8 grams protein $/ \mathrm{kg}$ SBW per d (plus 1 gram protein/gram Uprot.). Values are mean \pm SE for five subjects in each group.

ing since a HPD is known to stimulate leucine oxidation (12, $19)$ and would obscure the influence of proteinuria.

Plasma branched-chain amino acid (BCAA) levels. Plasma BCAA levels did not differ between nephrotic patients and control subjects while consuming either dietary regimen (Table II). In both groups, plasma BCAA levels increased significantly during feeding (except plasma valine during LPD in

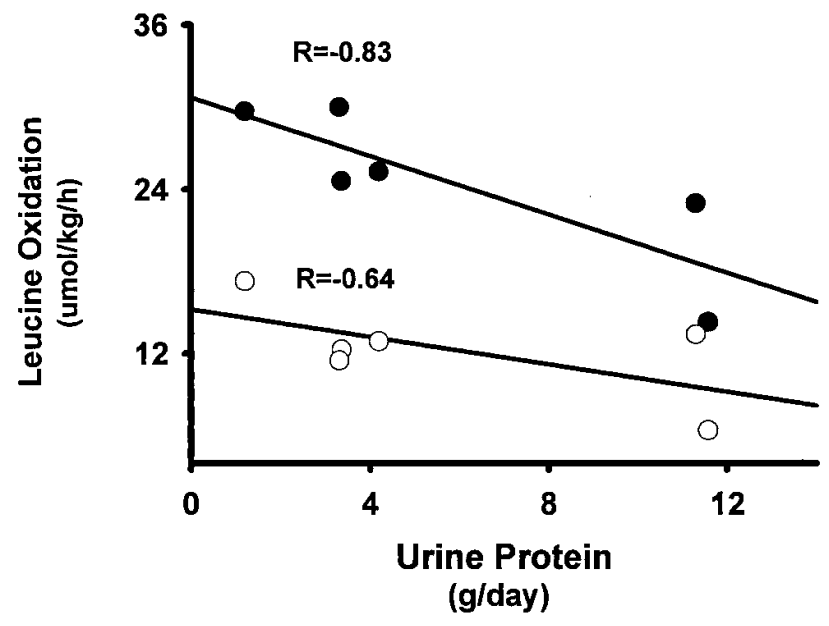

Figure 6. Relationship between urinary protein losses and leucine oxidation rates measured during fasting (open circles) and feeding (closed circles) while nephrotic subjects consumed the protein restricted diet. By linear regression there was a significant correlation during feeding $(P=0.04)$.

controls) and postprandial plasma BCAA levels were significantly greater with the HPD compared with the LPD.

\section{Discussion}

In theory, wasting in nephrosis could be due to an inadequate intake of protein or calories, catabolism induced by urinary protein losses, or a combination of these factors. In the past, high protein diets were recommended for nephrotic patients to compensate for urinary protein losses and to promote anabolism $(1,2)$. This recommendation was questioned when Kaysen et al. (3) reported that urinary albumin excretion decreased and serum albumin increased when nephrotic patients were fed a LPD providing 0.8 grams protein $/ \mathrm{kg}$ per d compared with a HPD providing 1.6 grams protein $/ \mathrm{kg}$ per $\mathrm{d}$. The finding that dietary protein restriction reduces proteinuria (3) is also important because of the association between the de-

Table II. Plasma Branched-chain Amino Acid Levels Measured during the Leucine Turnover Protocol in Nephrotic Patients and Control Subjects

\begin{tabular}{|c|c|c|c|c|c|c|}
\hline & \multicolumn{2}{|c|}{ Leucine } & \multicolumn{2}{|c|}{ Isoleucine } & \multicolumn{2}{|c|}{ Valine } \\
\hline & 1 & 2 & 1 & 2 & 1 & 2 \\
\hline & & & $\mu \mathrm{mol} /$ liter & & & \\
\hline \multicolumn{7}{|c|}{ Nephrotic } \\
\hline 0.8 & $103.9 \pm 4.4$ & $142.3 \pm 5.7 *$ & $56.3 \pm 5.6$ & $74.0 \pm 5.3^{*}$ & $173.9 \pm 7.3$ & $218.7 \pm 7.3^{*}$ \\
\hline 1.6 & $116.5 \pm 6.0$ & $195.7 \pm 5.5^{* \ddagger}$ & $58.3 \pm 3.3$ & $109.9 \pm 4.0^{* \frac{亠}{t}}$ & $202.0 \pm 8.4$ & $323.1 \pm 12.1^{* \neq}$ \\
\hline \multicolumn{7}{|c|}{ Control } \\
\hline 0.8 & $107.8 \pm 10.1$ & $122.5 \pm 9.2 *$ & $48.0 \pm 5.2$ & $57.5 \pm 6.4^{*}$ & $166.0 \pm 16.3$ & $191.3 \pm 19.0$ \\
\hline 1.6 & $121.1 \pm 13.0$ & $161.6 \pm 14.5^{* \ddagger}$ & $52.2 \pm 7.3$ & 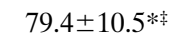 & $209.9 \pm 20.1$ & $282.6 \pm 24.4^{* \ddagger}$ \\
\hline
\end{tabular}

1, fasting; 2, feeding. Plasma branched-chain amino acid concentrations were measured between 10:30-11:30 a.m. (fasting) and 4:00-5:00 p.m. (feeding). Values are mean \pm SE for five patients $\left({ }^{*} P<0.0001\right.$; fasting vs feeding; ${ }^{\ddagger} P<0.0003,0.8$ vs 1.6 grams protein $/ \mathrm{kg}$ SBW per d diet). 
gree of proteinuria and progressive renal insufficiency $(4,31)$. Obviously, demonstrating the safety of prescribing a protein restricted diet in nephrosis is critical, since CRF patients may spontaneously reduce their dietary protein intake (32).

There are four principal conclusions derived from our results. First, a diet providing 0.8 grams protein (plus 1 gram protein/gram Uprot.) and $35 \mathrm{kcal} / \mathrm{kg}$ per day maintains neutral $\mathrm{B}_{\mathrm{N}}$ in patients with the nephrotic syndrome. Second, nephrotic patients achieve anabolism by activating adaptive responses similar to normal subjects. These responses included a postprandial stimulation of protein synthesis and inhibition of protein degradation resulting in net protein anabolism (i.e., protein synthesis $>$ protein degradation). The LPD also reduced amino acid oxidation thereby decreasing dietary EAA requirements. Third, the inverse correlation between urinary protein losses and feeding leucine oxidation rates measured while feeding the LPD (Fig. 6), suggests that proteinuria is an additional stimulus to suppress amino acid catabolism. Thus, the net response over $24 \mathrm{~h}$ was neutral or positive $\mathrm{B}_{\mathrm{N}}$ with either dietary regimen. Based on these considerations we conclude that urinary protein losses do not increase protein and amino acid catabolism in nephrosis.

In patients with CRF consuming a very low protein diet (VLPD) supplemented with EAA or with their nitrogen-free ketoanalogs (KA), we found that the primary anabolic response to feeding was a reduction in proteolysis; i.e., protein synthesis was unchanged or decreased slightly during feeding $(10,19)$. Although it is generally accepted that feeding stimulates amino acid oxidation and suppresses whole-body protein degradation, the impact of feeding on protein synthesis is more variable $(33,34)$. The postprandial stimulation of protein synthesis appears to be dependent upon the availability of amino acids, limited in part by the concomitant suppression of protein degradation and the exogenous amino acid supply $(26,34$ 36). The lack of a postprandial increase in plasma amino acid levels likely explains why protein synthesis did not increase in CRF patients consuming the more restrictive VLPD regimen (10). In the present study, protein intake was greater and plasma amino acid levels increased during feeding (Table II), supporting the conclusions of Tessari et al. (36) and Castellino et al. (35), who found that protein synthesis was stimulated only when sufficient amino acids were provided to produce hyperaminoacidemia.

The protein intake estimated from the Kjeldahl nitrogen analysis of a duplicate diet was slightly greater than prescribed using the Nutritionist IV database (Table I). It has been appreciated for many years that the composition of the same foods will vary depending upon factors such as soil, climate, and methods of preservation (37). Indeed, the modest differences in nitrogen content we observed between the Nutritionist IV database and duplicate diet analyses (i.e., 5-11\%) are similar or $<11 \%$ average deviation in Kjeldahl nitrogen content of the same diet reported by Reifenstein, Albright, and Wells (37).

Despite its limitations (38), the $\mathrm{B}_{\mathrm{N}}$ technique is generally considered the gold standard for assessing protein requirements (13). One such limitation is that adults with stable weight and body composition can exhibit very positive $B_{N}$ when they are fed protein intakes above the requirement (39). Nitrogen balance was strongly positive during the HPD, particularly in the nephrotic patients, but the lack of an increase in body weight suggests that nitrogen retention was less than predicted from the $\mathrm{B}_{\mathrm{N}}$ measurements. Data from mice, rats, dogs, and humans fed high nitrogen intakes have demonstrated the same phenomenon (40-42). For instance, when healthy adults were fed 26-34 grams N/d for 28 to $42 \mathrm{~d}, \mathrm{~B}_{\mathrm{N}}$ remained strongly positive (up to +7.9 grams $\mathrm{N} / \mathrm{d}$ ), yet body weight and total body potassium did not increase to the degree predicted by the retained nitrogen (42). The mechanism(s) responsible for the apparent nitrogen retention during excess nitrogen intakes are not understood $(38,39)$.

The control subjects were on average younger than the nephrotic patients. Since protein requirements are primarily determined by lean body mass which declines with age, it could be argued that the elderly nephrotic patients might have a lower requirement when expressed per killigram body weight. In healthy adults there is no evidence that protein requirements are lower in the elderly; in fact, the efficiency of protein utilization may be decreased (13). In the present study, $\mathrm{B}_{\mathrm{N}}$ was neutral or positive in all nephrotic patients and was not correlated with age.

Can results from short-term studies be extrapolated to long-term dietary adequacy? A new steady-state in urea nitrogen excretion occurs within 7-12 d of changing the level of protein intake (43) and to ensure equilibration our patients initiated the diets $\sim 3$ wks before the $\mathrm{B}_{\mathrm{N}}$ measurements. Using a similar protocol, we found that $B_{N}$ remained neutral and rates of whole-body leucine turnover were identical when measured $\sim 3$ wk after initiation of the VLPD/KA regimen and after 1 year of dietary therapy in 6 nonnephrotic patients with advanced CRF (GFR, 18 $\pm 2 \mathrm{ml} / \mathrm{min}$ ) (19). Based on these considerations it seems likely that the normal adaptive responses that we identified in nephrotic patients $\sim 3 \mathrm{wk}$ after initiation of the LPD can be sustained during long-term therapy. However, caution must always be exercised when extrapolating longterm dietary adequacy from short-term studies. It is also important that patients treated with protein-restricted diets be monitored at regular intervals to ensure dietary compliance and that nutritional status is not compromised.

In contrast to our results in rats with experimental nephrosis $(5,6)$, we did not observe a significant decrease in leucine oxidation or urea nitrogen appearance in the nephrotic patients during either dietary regimen. We believe this can be explained by the fact that nephrotic patients received supplemental dietary protein to compensate for urinary protein losses and therefore their net intake of dietary protein (i.e., intake minus urinary losses) was similar to the control subjects (Table I). In contrast, the nephrotic and control rats received an identical diet so the net protein intake in the nephrotic rats was in fact, lower $(5,6)$. If no allowance were made for urinary protein losses, the net intake for a $70-\mathrm{kg}$ individual prescribed 0.8 grams protein $/ \mathrm{kg}$ per $\mathrm{d}$ and the range of proteinuria we studied (i.e., 3.0-14.5 grams Uprot./d), would vary between 0.59-0.76 grams protein/kg per d. Consequently, we designed the study to test whether a diet providing 0.8 grams protein (plus 1 gram protein/gram Uprot.) would yield neutral $\mathrm{B}_{\mathrm{N}}$ and it did.

On the other hand, our results do not define the minimum protein requirement for nephrotic patients, nor do they prove that supplementing dietary protein intake for urinary protein losses is necessary to achieve neutral $\mathrm{B}_{\mathrm{N}}$. Studies testing prescribed diets containing $0.45-0.8$ grams protein $/ \mathrm{kg}$ per $\mathrm{d}$ showed that serum albumin levels remained stable or increased during long-term therapy (see Table IV in reference 44), supporting the conclusion that dietary protein restriction 
is safe for nephrotic patients. Moreover, a very low protein diet providing $\sim 0.3$ grams protein $/ \mathrm{kg}$ per $\mathrm{d}$ supplemented with EAA resulted in nearly complete remission of the nephrotic syndrome in five patients with GFR $>30 \mathrm{ml} / \mathrm{min}$ caused by disorders that seldom remit spontaneously (44). Taken together, these results suggest that more severe protein restriction than prescribed in the present study is not only safe, but may also induce normalization of the serum albumin levels and a marked decrease in proteinuria. However, we cannot recommend using low-protein diets in nephrotic patients with extremely high levels of proteinuria ( $>15$ grams/d) or individuals receiving catabolic drugs or with superimposed catabolic illnesses (e.g., systemic lupus erythematosus), since their safety has not been demonstrated in these settings.

In conclusion, our study indicates that clinically stable patients with the nephrotic syndrome can maintain protein homeostasis when fed a diet providing 0.8 grams protein (plus 1 gram protein/gram Uprot.) and $35 \mathrm{kcal} / \mathrm{kg}$ per day. These results have practical implications since LPDs delay the onset of uremic symptoms, decrease proteinuria, and secondary hypercholesterolemia in nephrosis (7), and may slow the rate of progression of renal failure $(8,14)$.

\section{Acknowledgments}

The authors wish to thank the nursing staff, dieticians, and core laboratory personnel in the Emory General Clinical Research Center for their assistance.

This work was supported by National Institutes of Health grants RO1DK40907, P50DK45215, and grant MO1RR-00039 from the Division of Research Resources, General Clinical Research Centers Program

\section{References}

1. Farr, L.E. 1938. The assimilation of protein by young children with the nephrotic syndrome. Am. J. Med. Sci. 195:70-83.

2. Blainey, B.J.D. 1954. High protein diets in the treatment of the nephrotic syndrome. Clin. Sci. 13:567-581.

3. Kaysen, G.A., J. Gambertoglio, I. Jimenez, H. Jones, and F.N. Hutchinson. 1986. Effect of dietary protein intake on albumin homeostasis in nephrotic patients. Kidney Int. 29:572-577.

4. Benigni, A., and G. Remuzzi. 1996. Glomerular protein trafficking and progression of renal disease to terminal uremia. Semin. in Nephrol. 16:151-159.

5. Choi, E.-J., R.C. May, J. Bailey, T. Masud, A. Dixon, and B.J. Maroni. 1993. Mechanisms of adaptation to proteinuria in adriamycin nephrosis. Am.J. Physiol. 265:F257-F263.

6. Choi, E.-J., J. Bailey, T. Masud, R.C. May, and B.J. Maroni. 1994. Metabolic responses to nephrosis: the effect of a low-protein diet. Am. J. Physiol. 266:F432-F438.

7. Kaysen, G.A. 1988. Albumin metabolism in the nephrotic syndrome: the effect of dietary protein intake. Am. J. Kidney Dis. 12:461-480.

8. Pedrini, M.T., A.S. Levey, J. Lau, T.C. Chalmers, and P.H. Wang. 1996. The effects of dietary protein restriction on the progression of diabetic and nondiabetic renal diseases: a meta-analysis. Ann. Intern. Med. 124:627-632.

9. Kopple, J.D., and J.W. Coburn. 1973. Metabolic studies of low protein diets in uremia: I. Nitrogen and potassium. Medicine (Baltimore). 52:583-595.

10. Masud, T., V.R. Young, T. Chapman, and B.J. Maroni. 1994. Adaptive responses to very low protein diets: the first comparison of ketoacids to essential amino acids. Kidney Int. 45:1182-1192.

11. Walser, M., A.W. Coulter, S. Dighe, and F.R. Crantz. 1973. The effect of keto-analogues of essential amino acids in severe chronic uremia. J. Clin. Invest. 52:678-690.

12. Goodship, T.H.J., W.E. Mitch, R.A. Hoerr, D.A. Wagner, T.I. Steinman, and V.R. Young. 1990. Adaptation to low-protein diets in renal failure: leucine turnover and nitrogen balance. J. Am. Soc. Nephrol. 1:66-75.

13. FAO/WHO/UNU. 1985. Energy and protein requirements. In Technical Report Series 724. World Health Organization, Geneva. 206 pp.

14. Jacobson, H.R., and G.E. Striker. 1995. Report on a workshop to develop management recommendations for the prevention of progression in chronic renal disease. Am. J. Kidney Dis. 25:103-106.
15. Frisancho, A.R. 1990. Anthropometric standards for the Assessment of Growth and Nutritional Status. University of Michigan, Ann Arbor, MI. 189 pp.

16. Klahr, S., A.S. Levey, G.J. Beck, A.W. Caggiula, L. Hunsicker, J.W. Kusek, G. Striker, and The Modification of Diet in Renal Disease (MDRD) Study Group. 1994. The effects of dietary protein restriction and blood pressure control on the progression of chronic renal disease. N. Engl. J. Med. 330:877-884.

17. Kopple, J.D., F.J. Monteon, and J.K. Shaib. 1986. Effect of energy intake on nitrogen metabolism in nondialyzed patients with chronic renal failure. Kidney Int. 29:734-742.

18. Maroni, B.J., T. Steinman, and W.E. Mitch. 1985. A method for estimating nitrogen intake of patients with chronic renal failure. Kidney Int. 27:58-65.

19. Tom, K., V. Young, R.T. Chapman, T. Masud, L. Akpele, and B.J. Maroni. 1994. Long-term adaptive responses to dietary protein restriction in chronic renal failure. Am. J. Physiol. 4:E668-E677.

20. Schoeller, D.A., P.D. Klein, J.B. Watkins, T. Heim, and W.C. MacLean, Jr. $1980 .{ }^{13} \mathrm{C}$ abundances of nutrients and the effect of variations in ${ }^{13} \mathrm{C}$ isotopic abundances of test meals formulated for ${ }^{13} \mathrm{CO}_{2}$ breath tests. Am. J. Clin. Nutr. 33:2375-2385.

21. Hoerr, R.A., Y.-M. Yu, D.A. Wagner, J.F. Burke, and V.R. Young. 1989. Recovery of ${ }^{13} \mathrm{C}$ in breath from $\mathrm{NaH}^{13} \mathrm{CO}_{3}$ infused by gut and vein: effect of feeding. Am. J. Physiol. 257:E426-E438.

22. Abumrad, N.N., D. Rabin, M.P. Diamond, and W.W. Lacy. 1981. Use of a heated superficial hand vein as an alternative site for the measurement of amino acid concentrations and for the study of glucose and alanine kinetics in man. Metab. Clin. Exp. 30:936-940.

23. Matthews, D.E., K.S. Motil, D.R. Rohrbaugh, J.F. Burke, V.R. Young, and D.M. Bier. 1980. Measurements of leucine metabolism in man from a primed continuous infusion of $\left[1-{ }^{13} \mathrm{C}\right]$ leucine. Am. J. Physiol. 238:E473-E479.

24. Horber, F.F., C.M. Horber-Feyder, S. Krayer, W.F. Schwenk, and M.W. Haymond. 1989. Plasma reciprocal pool specific activity predicts that of intracellular free leucine for protein synthesis. Am. J. Physiol. 257:E385-E399.

25. Hoerr, R.A., D.E. Matthews, D.M. Bier, and V.R. Young. 1991. Leucine kinetics from $\left[{ }^{2} \mathrm{H}_{3}\right]$ - and $\left[{ }^{13} \mathrm{C}\right]$ leucine infused simultaneously by gut and vein. Am. J. Physiol. 251:E111-E117.

26. Nissen, S., and M.W. Haymond. 1986. Changes in leucine kinetics during meal absorption: effects of dietary leucine availability. Am. J. Physiol. 250: E695-E701.

27. Adams, R.F. 1974. Determination of amino acid profiles in biological samples by gas chromatography. J. Chromatogr. 95:189-212.

28. Chaves das Neves, H.J., and A.M.P. Vasconcelos. 1987. Capillary gas chromatography of amino acids, including asparagine and glutamine: sensitive gas chromatographic mass spectrometric and selective ion monitoring gas chromatographic-mass spectrometric detection of the N.O. (S) -tert butyldimethylsilyl derivatives. J. Chromatogr. 392:249-258.

29. Rocchiccioli, F., J.P. Leroux, and P. Cartier. 1981. Quantitation of 2-ketoacids in biological fluids by as chromatography chemical ionization mass spectrometry of o-trimethylsilyl-quinoxalinol derivatives. Biomed. Mass. Spectrom. 8:160-164.

30. Langenbeck, U., H. Luthe, and G. Schaper. 1985. Ketoacids in tissues and biological fluids: O-t-butyldimethylsilyl quinoxalinols as derivatives for sensitive gas chromatographic/mass spectrometric determination. Biomed. Mass. Spectrom. 12:507-509.

31. Peterson, J.C., S. Adler, J.M. Burkart, T. Greene, L.A. Hebert, L.G. Hunsicker, A.J. King, S. Klahr, S.G. Massry, and J.L. Seifter. 1995. Blood pressure control, proteinuria and the progression of renal disease. Ann. Int. Med. 123:754-762.

32. Ikizler, T.A., J.H. Greene, R.L. Wingard, R.A. Parker, and R.M. Hakim. 1995. Spontaneous dietary protein intake during progression of chronic renal failure. J. Am. Soc. Nephrol. 6:1386-1391.

33. McNurlan, M.A., and P.J. Garlick. 1989. Influence of nutrient intake on protein turnover. Diabetes Metab. Rev. 5:165-189.

34. Pacy, P.J., G.M. Price, D. Halliday, M.R. Quevedo, and D.J. Millward 1994. Nitrogen homeostasis in man: the diurnal responses of protein synthesis and degradation and amino acid oxidation to diets with increasing protein intakes. Clin. Sci. 86:103-118.

35. Castellino, P., L. Luzi, D.C. Simonson, M. Haymond, and R.A. DeFronzo. 1987. Effect of insulin and plasma amino acid concentrations on leucine metabolism in man. J. Clin. Invest. 80:1784-1793.

36. Tessari, P., S. Inchiostro, G. Biolo, R. Trevisan, G. Fantin, M.C. Marescotti, E. Lori, A. Tiengo, and G. Crepaldi. 1987. Differential effects of hyperinsulinemia and hyperaminoacidemia on leucine-carbon metabolism in vivo. $J$. Clin. Invest. 79:1062-1069.

37. Reifenstein, E.C., F. Albright, and S.L. Wells. 1945. The accumulation, interpretation, and presentation of data pertaining to metabolic balances, notably those of calcium, phosphorus, and nitrogen. J. Clin. Endocrinol. 5:367-395.

38. Bier, D.M. 1989. Intrinsically difficult problems: the kinetics of body proteins and amino acids in man. Diabetes Metab. Rev. 5:111-132.

39. Kopple, J.D. 1987. Uses and limitations of the balance technique. $J$. Parenter. Enteral Nutr. 11:79S-85S.

40. Oddoye, A.E., and S. Margen. 1979. Nitrogen balance studies in humans: long-term effect of high nitrogen intake on nitrogen accretion. J. Nutr. 109:363-377. 
41. Costa, G. 1960. Hypothetical pathway of nitrogen metabolism. Nature (Lond.). 188:549-552.

42. Fisher, H., M.K. Brush, P. Griminger, and E.R. Sostman. 1967. Nitrogen retention in adult man: a possible factor in protein requirements. Am. J. Clin. Nutr. 20:927-934.

43. Rand, W.M., N.S. Scrimshaw, and V.R. Young. 1981. Conventional
("LONG-TERM") nitrogen balance studies for protein quality evaluation in adults: rationale and limitations. In Protein Quality in Humans: Assessment and In Vitro Estimation. C.E. Bodwell, J.S. Adkins, and D.T. Hopkins, editors. AVI Publishing Co., Inc. Westport. 61-97.

44. Walser, M., S. Hill, and E.A. Tomalis. 1996. Treatment of nephrotic adults with a supplemented, very low-protein diet. Am. J. Kidney Dis. 28:354-364. 